\title{
CORRESPONDENCE
}

\section{More Means Worse}

SIR,-In your issue of January $15^{1}$, your staff open their report of the Cambridge education conference by saying that everybody at it rejects the Amis view that "more means worse". That is a vulgár misquotation which perhaps recommends itself to educational expansionists by being easy to dismiss as "narrow", "facile", and so on.

What I wrote (in 1960), displaying no more than ordinary powers of prophecy, was "more will mean worse"; this in the context of arguing that, if you stop caring about university admission standards and allow simple desire for higher education to be the chief passport to it, you will produce less well educated graduates. Those who, like your staff and/or the participants at the conference, plus lower forms of life like the education correspondent of The Times, don't know what I said about more and worse, clearly can't know my arguments for saying it, and are in no position to "reject" a "view" I have never stated or held.

I would not, of course, use the same phrase today. Overcoming my dislike of stating what is perfectly obvious and more and more widely accepted (outside places like your columns and education conferences), I should have to write, "More has meant worse".

Yours faithfully,

KingSLEY AmIS

\section{Lemmons,}

Hadley Common,

Barnet, Hertfordshire

${ }^{1}$ Nature, 229, 159 (1971).

\section{Careers in Government R \& D}

Sir,-I am afraid that your editorial (Nature, 230, 334; 1971) misunderstood the basis of the CBI's proposals for broadening career prospects for people entering government research and development. The purpose of the shortterm appointment was to offer the opportunity for a few years government service as an alternative to entering government science as a life's career. Incidentally, initial reactions from government suggest that their thinking is on broadly similar lines, so I hope that CBI will still have some friends in government laboratories!

As for the rest of your comments, the CBI's proposals called for just the same opportunities for lateral movements with- in government service as your own commentary suggested and we explained how this might be achieved.

You will be interested to hear that we have other papers on various aspects of government and its research and development in preparation. We felt the paper on careers to be the most important since a flexible career-structure will make it easier for government to introduce any future changes in emphasis of government research and development.

Yours faithfully,

\section{P. M. KNOWLSON}

Confederation of British Industry,

21 Tothill Street,

London $S W 1$

\section{Uses of Education}

SIR,-I should like to comment on Sir Eric Ashby's analysis of what is wrong with university education today (Nature, 230,$283 ; 1971$ ), because I believe that in supporting the remedies proposed by Pippard et al. he fails to grasp the nettle.

Universities may well stand for excellence, objectivity, the cultivation of reason and the inherent value of knowledge, but unfortunately so many people, parents, employers and government departments believe that they stand principally as professional qualifying bodies. The former of these roles is much the more important, yet it is hardly for such purposes that universities have multiplied and grown in size over the past decade. Let us be clear that the reason most students compete for university entrance is not the altruistic one of promoting excellence and so on but to acquire a qualification which has high market value. Would it not be better to recognize frankly that the ethos of the university is quite different from the requirements of students and employers? Surely it would be better to concentrate on the development of excellence in research and the pursuit of knowledge for its own sake in a relatively few centres, the well established universities with traditions of high scholarship and research, institutions which are not missionorientated. They would be helped in this role if they did not hold examinations or award degrees. It is enough to have worked in a university with its high standards of scholarship and discipline, and consequently students would be attracted only if they were truly interested in study and research.

A wide field would then be left open for the development of qualitying schools for the professions having an ethos coincident with the requirements of employers and of students seeking reliable qualifications relevant to the jobs they expect to take up. Such institutions might be developed from existing universities and from polytechnics and colleges of advanced technology by changing their present functions. These could properly be called polytechnics, a term which would acquire high status as soon as they were recognized as the only professional training and qualifying centres. In some cases they could develop side by side with universities on the same campus. Unlike universities, the new polytechnics would be mission-orientated and their role would be to train and examine students in: (a) knowledge relevant to a profession; (b) the critical evaluation of information; (c) the execution of individual and collaborative projects; $(d)$ decision making in relation to practical problems and social needs.

The teaching staffs would be selected and promoted on their ability and success in teaching. Instead of undertaking academic research, they would be expected to tune themselves to the requirements of government and the professions by practising in national institutions and in industry on an exchange basis for, say, one year in four.

As a scientist employed in industry, I believe that such a scheme would be workable and would be welcomed by professional staffs who would have a regular opportunity of studying in some depth recent advances in their specialities, while teaching students about practical applications of their studies in real life.

Yours faithfully,

\section{A. C. Mason}

12 Collingham Green,

Little Sutton,

Wirral,

Cheshire L66 4NX

\section{Women's Liberation and Parenthood}

SIR,-With regard to your editorial on "Taxation and Women's Liberation" (Nature, 230, 345; 1971) I must strongly protest.

It is by no means "well demonstrated" that a parent pursuing a "profession" is unable to provide the kind of attention that young children require. Your statement could imply children raised by working class women who are compelled 